\title{
Greenhouse gas emission quantification from wastewater treatment plants, using a tracer gas dispersion method
}

Delre, Antonio; Mønster, Jacob; Scheutz, Charlotte

\section{Published in:}

Science of the Total Environment

Link to article, DOI:

10.1016/j.scitotenv.2017.06.177

Publication date:

2017

Document Version

Peer reviewed version

Link back to DTU Orbit

Citation (APA):

Delre, A., Mønster, J., \& Scheutz, C. (2017). Greenhouse gas emission quantification from wastewater treatment plants, using a tracer gas dispersion method. Science of the Total Environment, 605-606, 258-268.

https://doi.org/10.1016/j.scitotenv.2017.06.177

\section{General rights}

Copyright and moral rights for the publications made accessible in the public portal are retained by the authors and/or other copyright owners and it is a condition of accessing publications that users recognise and abide by the legal requirements associated with these rights.

- Users may download and print one copy of any publication from the public portal for the purpose of private study or research.

- You may not further distribute the material or use it for any profit-making activity or commercial gain

- You may freely distribute the URL identifying the publication in the public portal 


\section{Greenhouse gas emission quantification from wastewater treatment plants, using a tracer gas dispersion method}

Delre, A., Mønster, J., Scheutz, C.

Published in

Science of the Total Environment

DOI:

10.1016/j.scitotenv.2017.06.177

Publication date:

2017

Document Version

Author final version (often known as postprint)

Citation:

Delre, A., Mønster, J., Scheutz, C., 2017. Greenhouse gas emission quantification from wastewater treatment plants, using a tracer gas dispersion method. Science of the Total Environment, 605-606, 258-268.

doi:10.1016/j.scitotenv.2017.06.177 


\section{Greenhouse gas emission quantification from wastewater treatment plants, using a tracer gas dispersion method}

Antonio Delre ${ }^{a}$ *, Jacob Mønster ${ }^{b}$, Charlotte Scheutz ${ }^{\text {a }}$

Department of Environmental Engineering, Technical University of Denmark, Bygningstorvet, Bygning 115, 2800 Kgs. Lyngby, Denmark

a antodel@env.dtu.dk; b jagm@env.dtu.dk; ' chas@env.dtu.dk

* Corresponding author: chas@env.dtu.dk 


\section{Highlights}

- Plant-integrated $\mathrm{CH}_{4}$ and $\mathrm{N}_{2} \mathrm{O}$ emissions were measured at five WWTPs

- Emissions were quantified using a ground-based remote sensing approach

- $\mathrm{CH}_{4}$ emission factors were between 1 and $21 \%$ of $\mathrm{CH}_{4}$ production

- $\mathrm{N}_{2} \mathrm{O}$ emission factors ranged from below detection to $5.2 \%$ of total nitrogen influent

- Models in guidelines were found inaccurate for site-specific emission reporting

\section{Keywords}

Methane, nitrous oxides, emission factor, ground-based remote sensing, IPCC guideline, anaerobic digestion

\section{Graphical abstract}

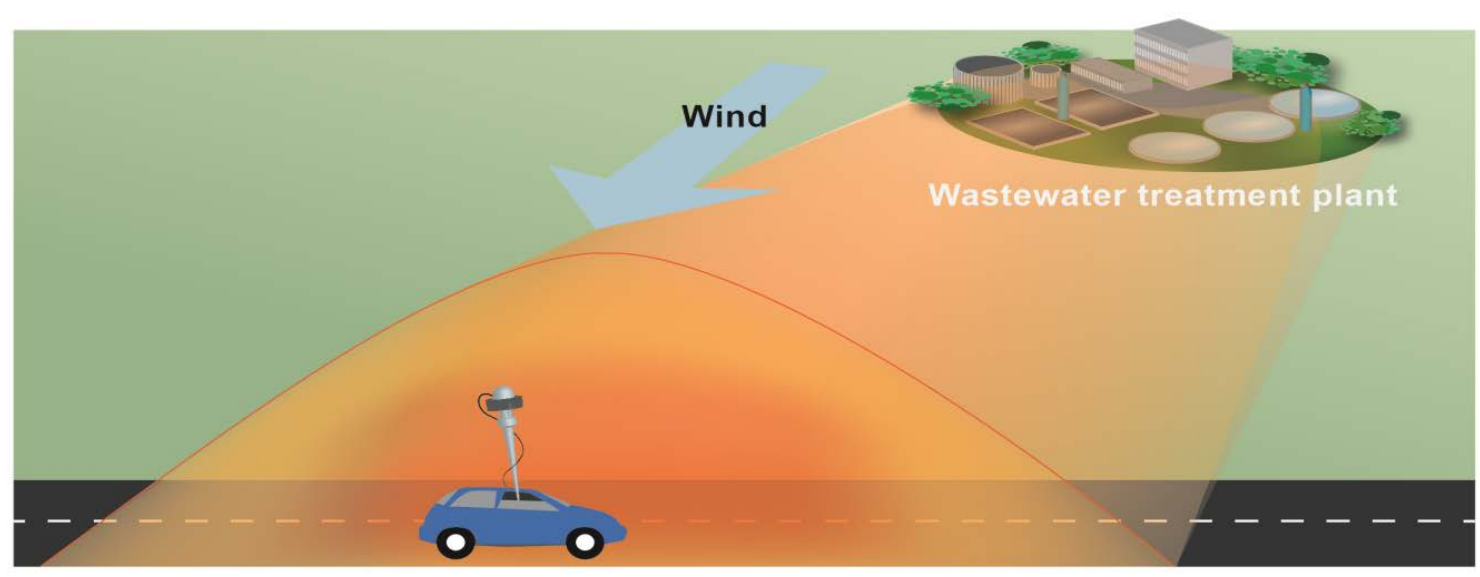




\section{Abstract}

Plant-integrated methane $\left(\mathrm{CH}_{4}\right)$ and nitrous oxide $\left(\mathrm{N}_{2} \mathrm{O}\right)$ emission quantifications were performed at five Scandinavian wastewater treatment plants, using a ground-based remote sensing approach that combines a controlled release of tracer gas from the plant with downwind concentration measurements. $\mathrm{CH}_{4}$ emission factors were between 1 and $21 \%$ of $\mathrm{CH}_{4}$ production, and between 0.2 and $3.2 \%$ of COD influent. The main $\mathrm{CH}_{4}$ emitting sources at the five plants were sludge treatment and energy production units. The lowest $\mathrm{CH}_{4}$ emission factors were obtained at plants with enclosed sludge treatment and storage units. $\mathrm{N}_{2} \mathrm{O}$ emission factors ranged from $<0.1$ to $5.2 \%$ of TN influent, and from $<0.1$ to $5.9 \%$ of TN removed. In general, measurement-based, site-specific $\mathrm{CH}_{4}$ and $\mathrm{N}_{2} \mathrm{O}$ emission factors for the five studied plants were in the upper range of the literature values and default emission factors applied in international guidelines. This study showed that measured $\mathrm{CH}_{4}$ and $\mathrm{N}_{2} \mathrm{O}$ emission rates from wastewater treatment plants were plant-specific and that emission rates estimated using models in current guidelines, mainly meant for reporting emissions on the country scale, were unsuitable for Scandinavian plant-specific emission reporting. 


\section{Introduction}

The United Nations Framework Convention on Climate Change promotes the reporting of national greenhouse gas (GHG) emissions from anthropogenic activities as an important instrument to curb global climate change. Wastewater treatment is an anthropogenic source of methane $\left(\mathrm{CH}_{4}\right)$ and nitrous oxide $\left(\mathrm{N}_{2} \mathrm{O}\right)$ (Daelman et al., 2013), two potent GHGs (Stocker et al., 2013), which are responsible for the largest part of a wastewater treatment plant's (WWTP's) carbon footprint (Daelman et al., 2013; Yoshida et al., 2014a, 2014b).

In the European Union, WWTPs have to report their environmental emissions to the European Pollutant Release and Transfer Register (E-PRTR), which is a publicly accessible inventory of environmental emissions caused by human activities. Only WWTPs for which emissions exceed specific thresholds are obliged to report their emissions to the E-PRTR, but some low-emission facilities state their releases on a voluntary basis (Petersson, 2012). Currently, WWTPs report their emissions mainly by following the guideline provided by the Intergovernmental Panel on Climate Change (IPCC) (Doorn et al., 2006). It is, however, unknown as to what extent the IPCC guideline provides realistic and valid emission estimation models for plant-specific GHG emission reporting. In this context, quantification of plant-specific emissions is needed, to assure reliable emission reporting and WWTP carbon footprint evaluation. However, quantifying GHG emissions from WWTPs is a challenging undertaking, as a WWTP comprises many different process units and technologies, resulting in a large emitting area consisting of several smaller sources made up of different physical shapes and emission heights. Additionally, specific plant operation conditions result in temporal variations in emissions.

In the last twenty years, emissions have been measured mainly by applying on-site point measurement methods. Floating chambers combined with liquid sample analysis have been the most common way of measuring $\mathrm{N}_{2} \mathrm{O}$ and $\mathrm{CH}_{4}$ emissions from wastewater reactors and investigating temporal and spatial variability (Kampschreur et al., 2009; Rodriguez-Caballero et al., 2014). Only a few studies have performed measurements on enclosed treatment technologies, equipped with an air collection system, to obtain a large dataset with diurnal and annual changes (Daelman et al., 2013; Toyoda et al., 2011). However, this approach cannot be applied to open-air process units, and it does not consider GHG leakages from pipes, fittings, pressure release vents, 
or any other incidental releases. On-site point measurement methods have also been used for measuring $\mathrm{CH}_{4}$ releases from installations at biogas plants using various substrates, including manure and solid waste, which are equipped with treatment processes and technologies also used for anaerobic digestion of sewage sludge. These studies usually involve leakage identification followed by emission quantification, using the flux chamber technique (Liebetrau et al., 2013).

In recent years, ground-based optical remote sensing approaches have also been used for quantifying diffuse GHG emissions. Two studies combined downwind $\mathrm{CH}_{4}$ concentrations, using open-path gas analyzers with backward Lagrangian Stochastic modeling, to determine $\mathrm{CH}_{4}$ emissions from a biogas plant (Flesch et al., 2011; Reinelt et al., 2017). Application of a tracer gas dispersion method, coupled with a mobile, highly sensitive analytical platform, provided plant-integrated emission rates from an open-air WWTP by measuring the downwind plumes of both $\mathrm{CH}_{4}$ and $\mathrm{N}_{2} \mathrm{O}$ (Yoshida et al., 2014b). Recent studies at WWTPs and biogas plants suggest that groundbased optical remote sensing methods provide a more comprehensive overview of $\mathrm{CH}_{4}$ emissions from area sources (Jensen et al. 2017; Reinelt et al., 2017; Yver Kwok et al., 2015).

Knowledge on plant-integrated emission rates is important for site-specific emission reporting, environmental assessment, and system performance optimization. The generation of new emission factors (EFs) concerning total site emissions and reflecting current wastewater treatment technologies might be used to revise current EFs for the future reporting of national GHG emissions from wastewater treatment.

The objective of this study was to quantify the total emissions of $\mathrm{CH}_{4}$ and $\mathrm{N}_{2} \mathrm{O}$ at five Scandinavian WWTPs, using a tracer gas dispersion method, resulting in plant-integrated emission rates. The studied plants were equipped with different treatment technologies covering most of the wastewater and sewage sludge treatments in the geographical region. Based on the measured plant-integrated emission rates, EFs were determined, in order to compare direct emissions from the investigated plants as well as with EFs reported in the literature. Finally, emission rates based on measurements were compared with emission rates estimated following the IPCC and Danish guidelines. 


\section{Materials and methods}

\subsection{Investigated sites}

The studied WWTPs differed from each other in terms of pollution load, applied wastewater and sewage sludge treatment technologies, energy production and use, and additional waste material treated at the facilities. Table 1 provides an overview of the five WWTPs, showing their location, treatment capacity (expressed as population equivalent (PE)), and main treatment technologies. Table 1 splits the treatment phases into three lines: Wastewater treatment, sludge treatment, and energy utilization. Preliminary wastewater treatment removing coarse parts, grit, and grease, and sedimentation tanks, were common to all sites and were thus not included in Table 1. The wastewater line includes process units such as main treatment reactors, the side treatment of reject water from the sludge line, and advanced treatments for meeting more stringent discharge requirements. The sludge treatment line considers five steps: Sludge storage after its removal from wastewater, anaerobic digestion, digestate storage, digestate treatment, and final biosolids treatment or storage.

During treatment, sewage sludge can be referred to in different ways. The following nomenclature is used to distinguish the different treatment stages. After being removed from wastewater, sewage sludge is called "substrate" when entering the digester. The liquid output from the digestion process is called "digestate," which, after increasing its solid content via centrifugation or other dewatering technologies, is called "biosolids". Table 1 also shows the energy generation line, which considers biogas use and upgrading.

All five WWTPs performed advanced biological nitrogen removal, but only Holbæk and Växjö treated reject water before recirculation. The main biological treatment of wastewater was performed with different technologies such as biodenitro, sequencing batch bioreactors, activated sludge, and moving bed bioreactors. All plants stabilized sewage sludge through anaerobic digestion, albeit with different storage methods for substrate, digestate, and biosolids. In Växjö, biosolids were stored in on-site stockpiles for six months, while in the two largest plants (Lundtofte and Lynetten), digestate was dewatered, dried, and incinerated on-site. In Holbæk and Källby, the storage and further treatment of biosolids occurred off-site at an external facility. All plants produced biogas, but only at the Swedish plants (Källby and Växjö) was the generated biogas upgraded to biomethane. 
Table 1. Overview of the investigated wastewater treatment plants.

\begin{tabular}{|c|c|c|c|c|c|c|c|c|c|c|c|c|}
\hline \multirow[b]{2}{*}{ Plant } & \multirow[b]{2}{*}{$\begin{array}{l}\text { Population } \\
\text { Equivalent } \\
\text { (x 1,000) }\end{array}$} & \multicolumn{3}{|c|}{ Wastewater treatment line } & \multicolumn{5}{|c|}{ Sludge treatment line } & \multicolumn{2}{|l|}{ Energy line } & \multirow[b]{2}{*}{$\begin{array}{l}\text { Additional } \\
\text { processed } \\
\text { materials }\end{array}$} \\
\hline & & $\begin{array}{l}\text { Main } \\
\text { reactors }\end{array}$ & $\begin{array}{l}\text { Side } \\
\text { treatment }\end{array}$ & $\begin{array}{l}\text { Advanced } \\
\text { treatment }\end{array}$ & $\begin{array}{l}\text { Sludge } \\
\text { storage \& } \\
\text { treatment }\end{array}$ & $\begin{array}{l}\text { Substrate } \\
\text { digestion }\end{array}$ & $\begin{array}{l}\text { Digestate } \\
\text { storage }\end{array}$ & $\begin{array}{l}\text { Digestate } \\
\text { treatment }\end{array}$ & $\begin{array}{l}\text { Biosolids } \\
\text { treatment }\end{array}$ & $\begin{array}{l}\text { Biogas } \\
\text { use }^{\text {a }}\end{array}$ & $\begin{array}{l}\text { Biogas } \\
\text { upgrading }\end{array}$ & \\
\hline $\begin{array}{l}\text { Holbæk } \\
\text { (DK) }\end{array}$ & 60 & SBR & $\begin{array}{l}\text { Deammo- } \\
\text { nification } \\
\text { process }\end{array}$ & Sand filter & $\begin{array}{l}\text { Outdoor } \\
\text { open } \\
\text { tank }\end{array}$ & $\begin{array}{l}12-15 \\
\text { days }\end{array}$ & $\begin{array}{l}\text { Outdoor } \\
\text { open } \\
\text { tank }\end{array}$ & $\begin{array}{l}\text { Enclosed } \\
\text { thickening } \\
\text { and indoor } \\
\text { dewatering }\end{array}$ & $\begin{array}{l}\text { Outdoor } \\
\text { storage } \\
\text { for } 2 \text { days }\end{array}$ & $\begin{array}{l}\text { Combined } \\
\text { heat and } \\
\text { power } \\
\text { engine }\end{array}$ & None & $\begin{array}{l}\text { Landfill } \\
\text { leachate and } \\
\text { biological } \\
\text { sludge from } \\
\text { two smaller } \\
\text { WWTPs }\end{array}$ \\
\hline $\begin{array}{l}\text { Växjö b } \\
\text { (SE) }\end{array}$ & 95 & 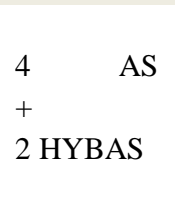 & $\begin{array}{l}\text { Deammo- } \\
\text { nification } \\
\text { process }\end{array}$ & Sand filter & Indoor & $\begin{array}{l}17-22 \\
\text { days } \\
\text { after } \\
\text { THP }\end{array}$ & Indoor & $\begin{array}{l}\text { Indoor } \\
\text { thickening } \\
\text { and dewater- } \\
\text { ing }\end{array}$ & $\begin{array}{l}\text { Outdoor on } \\
\text { stockpiles } \\
\text { for } 6 \\
\text { months }\end{array}$ & $\begin{array}{l}\text { Partly sold } \\
\text { as vehicle } \\
\text { gas }\end{array}$ & $\begin{array}{l}\text { Amine } \\
\text { Scrubber }\end{array}$ & $\begin{array}{l}\text { Food waste } \\
\text { and sewage } \\
\text { sludge from } \\
\text { smaller } \\
\text { WWTPs }{ }^{\text {c }}\end{array}$ \\
\hline $\begin{array}{l}\text { Källby } \\
\text { (SE) }\end{array}$ & 120 & AS & None & $\begin{array}{l}\text { Flocculation } \\
\text { and clarifi- } \\
\text { cation } \\
\text { ponds }\end{array}$ & $\begin{array}{l}\text { Outdoor } \\
\text { open } \\
\text { tank }\end{array}$ & $\begin{array}{l}20-30 \\
\text { days }\end{array}$ & $\begin{array}{l}\text { Outdoor } \\
\text { open } \\
\text { tank }\end{array}$ & $\begin{array}{l}\text { Thickening } \\
\text { outdoor in } \\
\text { open tank, } \\
\text { dewatering } \\
\text { indoor. }\end{array}$ & $\begin{array}{l}\text { Covered } \\
\text { silos } \\
\text { for } 1 \text { day }\end{array}$ & $\begin{array}{l}\text { Partly sold } \\
\text { as vehicle } \\
\text { gas }\end{array}$ & $\begin{array}{l}\text { Amine } \\
\text { Scrubber }\end{array}$ & $\begin{array}{l}\text { Sewage } \\
\text { sludge from } \\
\text { smaller } \\
\text { WWTPs }\end{array}$ \\
\hline $\begin{array}{l}\text { Lundtofte } \\
\text { (DK) }\end{array}$ & 150 & $\begin{array}{l}\text { Bio Deni- } \\
\text { tro and } \\
\text { Anaerobic } \\
\text { MBBR }\end{array}$ & None & MBR & $\begin{array}{l}\text { Outdoor } \\
\text { enclosed } \\
\text { tanks }\end{array}$ & $\begin{array}{l}22-25 \\
\text { days }\end{array}$ & Indoor & $\begin{array}{l}\text { Indoor } \\
\text { thickening } \\
\text { and dewater- } \\
\text { ing }\end{array}$ & $\begin{array}{l}\text { On-site } \\
\text { incineration }\end{array}$ & $\begin{array}{l}\text { Partly sent } \\
\text { to the gas } \\
\text { network }\end{array}$ & None & None. \\
\hline $\begin{array}{l}\text { Lynetten } \\
\text { (DK) }\end{array}$ & 750 & $\begin{array}{l}\text { Bio Deni- } \\
\text { pho }\end{array}$ & None & None & $\begin{array}{l}\text { Outdoor } \\
\text { enclosed } \\
\text { tank }\end{array}$ & $\begin{array}{l}15-22 \\
\text { days }\end{array}$ & $\begin{array}{l}\text { Outdoor } \\
\text { enclosed } \\
\text { tank }\end{array}$ & $\begin{array}{l}\text { Indoor } \\
\text { thickening } \\
\text { and dewater- } \\
\text { ing }\end{array}$ & $\begin{array}{l}\text { On-site } \\
\text { incineration }\end{array}$ & $\begin{array}{l}\text { Partly sent } \\
\text { to the gas } \\
\text { network }\end{array}$ & None & $\begin{array}{l}\text { Incineration } \\
\text { of external } \\
\text { dewatered } \\
\text { sludge }\end{array}$ \\
\hline
\end{tabular}

${ }^{a}$ All WWTPs use biogas produced on site. ${ }^{b}$ Biofilter consisting of compost intended for odor removal from off-gas emissions from indoor treatments. ${ }^{\mathrm{c}}$ The portion of food waste is 33\% of the total COD influent entering the plant, and 9\% of the TN influent entering the plant. MBBR: Moving Bed Bio Reactor. SBR: Sequencing Batch Reactors. AS: Activated Sludge. HYBAS: AS combined with MBBR. MBR: Membrane Bio Reactor. THP: Thermal Hydrolysis Process. 


\subsection{The tracer gas dispersion method}

GHG emission quantification from the WWTPs was carried out using a tracer dispersion method, i.e. a ground-based optical remote sensing method combining the controlled release of tracer gas with concentration measurements downwind of the facility. The application of tracer gases is a well-known approach for quantifying fugitive gas releases from diverse area sources, and recent developments in analytical technologies have made the tracer gas dispersion method an even more powerful and robust tool (Mønster et al., 2015; 2014; Scheutz et al., 2011; Yoshida et al., 2014b).

The tracer gas dispersion method is based on the principle that gases with long atmospheric lifetimes disperse in the same way in relation to mixing and transportation in the atmosphere, and thus the concentration ratio is constant over space (Mønster et al., 2014). As a consequence, the real-time emission rate of the target gas can be obtained by comparing the downwind plumes of the target gas and a tracer gas, whereby the latter is constantly released from the emitting area, as shown by Eq. 1.

$E_{t g}=Q_{t r} \cdot \frac{\int_{\text {plume start }}^{\text {plume end }}\left(C_{t g}-C_{\text {tg back }}\right) d x}{\int_{\text {plume start }}^{\text {plume end }}\left(C_{t r}-C_{\text {tr back }}\right) d x} \cdot \frac{M W_{t g}}{M W_{t r}}$ (Eq. 1)

$E_{t g}$ is target gas emission in mass per time; $Q_{t r}$ is tracer release in mass per time; $C_{t g}$ and $C_{t r}$ are measured downwind concentrations in parts per billion (ppb); $C_{t g \text { back }}$ and $C_{t r \text { back }}$ are background concentrations of the target and the tracer gas (ppb), and $M W_{t g}$ and $M W_{t r}$ are the molecular weights of the target gas and tracer gas, respectively (Scheutz et al., 2011). Concentrations were integrated over the plume's cross-section, to minimize the influence of improper source simulation and gas mixing (Mønster et al., 2014). Acetylene $\left(\mathrm{C}_{2} \mathrm{H}_{2}\right)$ was used as tracer gas because of its small atmospheric background level, minimal possible interfering sources, and long atmospheric lifetime (23 days) (Logan et al., 1981).

The tracer gas dispersion method was recently validated by performing a controlled release experiment simulating a $\mathrm{CH}_{4}$ source (Mønster et al., 2014). Mønster et al. (2014) showed that when tracer gas was placed close to the source, the measured emissions corresponded well with the controlled release at all three measuring distances tested (370, 770 and 1200 meters), with an average calculated emission value of no more than $6 \%$ from the released amount. The tracer gas dispersion method has been adopted by the Danish Environmental Protection Agency for reporting on landfill $\mathrm{CH}_{4}$ emissions and 
documenting emissions reductions, and these measurements are now being done routinely (EPA, 2016). The tracer gas dispersion method was applied for the first time at a Danish WWTP to quantify $\mathrm{CH}_{4}$ and $\mathrm{N}_{2} \mathrm{O}$ emissions (Yoshida et al., 2014b) and thereafter at a French WWTP for quantifying $\mathrm{CH}_{4}$ emission (Yver Kwok et al., 2015). Both studies were performed by the senior authors of this paper, using the same analytical instrumentation employed in this study.

Gas concentration measurements were performed using a mobile analytical platform equipped with fast-responding and highly sensitive gas analyzers, a weather station, and a global positioning system (GPS) device. Gas analyzers were based on cavity ring down spectroscopy - an optical technology in which gas concentration is obtained by measuring directly the "ring-down," or decay, of laser light in a sample cell. One instrument measured every second $\mathrm{CH}_{4}$ and $\mathrm{C}_{2} \mathrm{H}_{2}$ (G2203, Picarro, Inc., Santa Clara, CA), with a precision of 0.77 and $0.06 \mathrm{ppb}$, respectively. The second instrument measured every three seconds $\mathrm{N}_{2} \mathrm{O}$ and $\mathrm{C}_{2} \mathrm{H}_{2}$ (S/N JADS2001, Picarro, Inc., Santa Clara, CA), with a precision of 7.7 and $0.6 \mathrm{ppb}$, respectively. Instrument precision is the reproducibility of a measurement and was defined as the standard deviation when measuring a constant gas concentration for one hour. Atmospheric gas samples were taken from an inlet positioned on the roof of the vehicle, analyzed, and measured concentrations were showed real-time on monitors mounted in the driver's cabin. $\mathrm{C}_{2} \mathrm{H}_{2}$ was released from gas cylinders, the flow rates for which were controlled using calibrated flow meters. More details about the equipment can be found in Mønster et al. (2014) and Yoshida et al. (2014b).

The measurement campaigns consisted of two main phases: An initial screening phase (on-site and off-site) and a quantification phase. During the screening phase, the analytical instrument was driven around on-site the plant to record atmospheric concentrations of target gases. Emitting on-site sources were found when the target gas concentration downwind from the source was greater than the upwind concentration. At the beginning of each campaign, atmospheric concentrations were measured upwind, downwind, and around the WWTP, to ensure the absence of interfering off-site sources. Measurements performed upwind the facility were used to establish background concentrations. In case an off-site source was identified in the vicinity to a WWTP, measurements were performed under wind conditions and measuring distances where the plume from the source could be distinguished from the plume coming from the WWTP. Fig. 1 shows the two measurement phases 
consisting of on-site screening and downwind plume detection and emission quantification. On-site screening (Fig. 1A1) was performed to identify the main sources of the target gas at the facility and in order to simulate its emission properly with the right position for the release of the tracer gas. Fig. 1A2 shows an example of an on-site screening performed at Källby (SE), recording higher atmospheric concentrations of target gases when the analytical instrument drove downwind specific process units. Once the main sources of target gas were identified, tracer gas cylinders were placed close to them in order to properly simulate the emission of the target gas (Fig 1B1), and tracer gas was released in the atmosphere (Fig 1B2). Proper emission simulation with the tracer gas was always assured through a good downwind correlation of tracer and target gases. Quantification measurements (Fig 1C) were then taken downwind at a suitable distance away from the plant - far enough to enable proper mixing of tracer and target gas, i.e. good gas correlation, and close enough to get a good signal-to-noise ratio. Depending on the physical size of the plant and the accessibility in terms of roads, the measuring distance varied from 35 to 1,300 m. Fig. 2 shows two representative examples of downwind plumes.

Multiple transects across the downwind plume ensured that any change in atmospheric dispersion was the same for both gases (target gas and tracer gas) and for each individual plume measurement. Downwind traverses were considered complete if the whole plume was recorded. This allowed identification of background concentrations on both sides of each plume and established a baseline to be subtracted from the measurements (Eq. 1), thereby obtaining only the source's contribution to atmospheric concentrations (Fig. 2). 


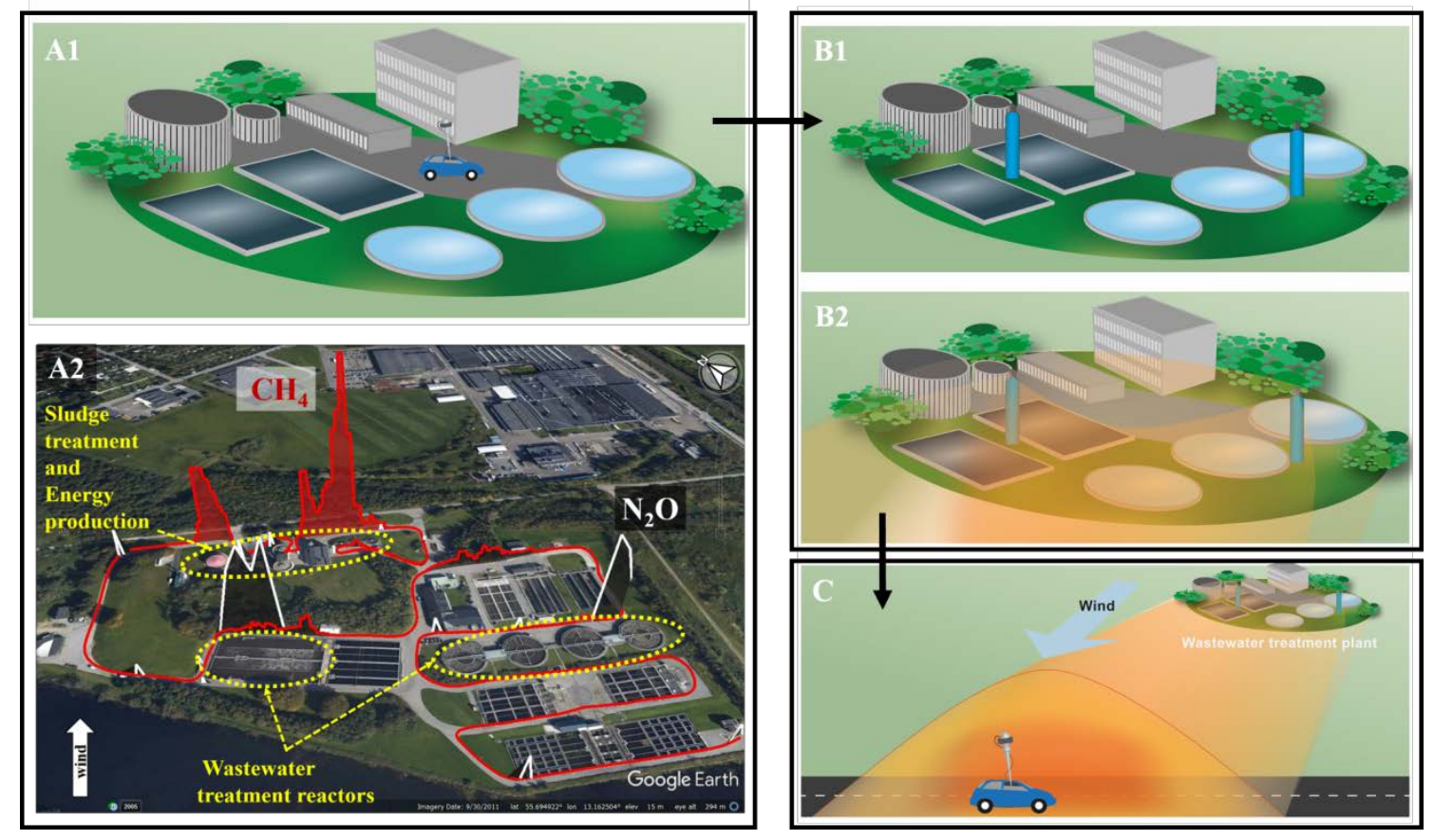

Fig. 1. Illustration of the tracer gas dispersion method applied at wastewater treatment plants. A) The initial screening phase with A1 showing on-site measurements of atmospheric concentrations of target and tracer gases and A2 showing an example of on-site screenings performed at Källby (SE) visualized on a Google Earth (c) image. $\mathrm{CH}_{4}$ (marked in red) and $\mathrm{N}_{2} \mathrm{O}$ (marked in white) concentrations are shown above the background level. The white arrow shows the wind direction. B) Tracer placement with B1 showing the location of the tracer gas for source simulation and B2 showing the release of the tracer gas into the atmosphere. C) The quantification phase showing downwind gas concentrations measurement performed along a plume transect. 


\subsection{Measurement campaigns}

Twenty-six measurement campaigns were conducted. Each WWTP was investigated several times (three to eight times), and, when possible, different wind directions were used to distinguish individual on-site sources and their associated emissions. The duration of the measurement campaigns varied from two to 11 hours, depending on weather conditions and WWTP access. Measurements were performed over as long a time period as possible, to cover process cycles and to capture potential temporal emission variations. An overview of the measurement campaigns can be found in the Supporting Information (SI), Table S1.

\subsection{Estimation of the lowest detectable emission rate}

The lowest detectable emission is a function of weather conditions, measuring distance, and the analytical instrument. Thus, the detection limit is specific to conditions in each field campaign. The detection limit of the emission rate was estimated using a novel approach based on inverse Gaussian plume modeling. This approach is a new approach aiming at the consistent and transparent determination of the detection limit of the tracer dispersion method, which was not applied in the previous works carried out with the same analytical setup (Mønster et al., 2014, 2015, Yoshida et al., 2014b).

The Gaussian plume model assumes that an emitting source produces a downwind plume, which can be described by a Gaussian distribution. The downwind plume's concentration is a result of atmospheric conditions, dispersion surface roughness, emission release height above ground level, distance from source, and the source emission rate. The model is described in Eq. (2):

$C(x, y, z)=\frac{Q}{2 \pi u \sigma_{y}(x) \sigma_{z}(x)} \cdot\left(e^{-0,5\left(\frac{z-H}{\sigma_{z}(x)}\right)^{2}}+e^{-0,5\left(\frac{z+H}{\sigma_{z}(x)}\right)^{2}}\right) e^{-0,5\left(\frac{y}{\sigma_{y}(x)}\right)^{2}}$

where $C$ is the concentration $\left(\mathrm{kg} \mathrm{m}^{-3}\right)$ in any given downwind plume point $(x, y, z)$ measured from the source; $Q$ is the emission rate $\left(\mathrm{kg} \mathrm{s}^{-1}\right) ; u$ is wind speed ( $\mathrm{m} \mathrm{s}^{-1}$ ); $\sigma_{y}(x)$ and $\sigma_{z}(x)$ are the dispersion coefficients (m); and $H$ is the emission height above ground level (m).

The minimum detectable emission rate $Q_{\min }$ was calculated from Eq. (2) by considering the following parameters. The smallest detectable downwind 
peak plume concentration $C_{\min }(x, 0,2)$ was set to equal a signal-to-noise ratio of 3 (Shrivastava and Gupta, 2011), and thus $C_{\min }$ was three times the magnitude of the background noise of $\mathrm{CH}_{4}$ and $\mathrm{N}_{2} \mathrm{O}$ on individual measurement days. $C_{\min }(x, 0,2)$ is the concentration in the center of the downwind plume $(y=0), x$ meters from the source, and at 2 meters above the ground $(z=2)$ (sample inlet of the instrument). Horizontal and vertical dispersion coefficients, $\sigma_{y}(x)$ and $\sigma_{z}(x)$, were calculated by following Briggs (1974) for different atmospheric stability classes and plume transportation in an urban area or open countryside. Atmospheric stability classes were chosen following Pasquill (1974), using insolation and cloud cover information as well as onsite atmospheric measurements (Table S1 in SI). 


\subsection{Assessment of uncertainty due to emission height}

In most cases, $\mathrm{CH}_{4}$ and $\mathrm{N}_{2} \mathrm{O}$ will be emitted from different sources at ground level. However, in situations where the emission occurs from an elevated height, such as $\mathrm{CH}_{4}$ releasing from the top of anaerobic digesters, and downwind plume transects are performed close to the site, there is a risk of underestimating the measured emission. Underestimation is possible because the target gas released at an elevated height has not completely mixed with the tracer gas released at ground level. A new approach for assessing the potential underestimation of emission rates due to elevated emission heights was introduced by using an indicator called "Underestimation due to Tracer Height release” (UTH). This information is useful, as it underlines how much a vertical misplacement of the tracer potentially could bias the results. Elevated sources such as venting processes in digesters are unpredictable events which could release from small to very large amounts of $\mathrm{CH}_{4}$, depending on many factors (Reinelt et al., 2015; Yoshida et al., 2014b). However, leaks from flares or stacks could also potentially bias the results. Eq. 3 expresses mathematically the UTH as the absolute value of the difference in percentage between the emission rates calculated with $\mathrm{C}_{2} \mathrm{H}_{2}$ released from the ground and emission rates calculated with $\mathrm{C}_{2} \mathrm{H}_{2}$ released from an elevated height.

$\operatorname{UTH}(\%)=\left|\left(1-\frac{P C_{C_{2} \mathrm{H}_{2} g}}{P C_{C_{2} \mathrm{H}_{2} h}}\right) \cdot 100\right|$ (Eq. 3)

$P C_{C_{2} H_{2} g}$ and $P C_{C_{2} H_{2} h}$ represent the downwind peak concentration (ppb) of the tracer gas estimated by the Gaussian plume model when the tracer is released from ground level and from an elevated height, respectively (Eq. 2). Since $P C_{C_{2} H_{2} g}>P C_{C_{2} H_{2} h}$, UTH is reported as an absolute value, because, by definition, it expresses an underestimation. UTH is thus specific to each measuring situation, as $P C_{C_{2} \mathrm{H}_{2} g}$ and $P C_{C_{2} \mathrm{H}_{2} h}$ are based on Gaussian plume modeling, using the specific input parameters mentioned in section 2.4. A more detailed explanation about UTH is available in SI, section S2. 


\subsection{GHG emission rate calculation following the IPCC international guideline}

The measured $\mathrm{CH}_{4}$ and $\mathrm{N}_{2} \mathrm{O}$ emission rates were compared to estimated emission rates obtained by applying the IPCC guideline (Doorn et al., 2006). For $\mathrm{CH}_{4}$ emission estimation, the IPCC guideline suggests three different tierbased approaches, depending on the available information. All three approaches consider plant-specific information but use different EFs. Tier 1 adopts an emission estimation model with default EFs, while Tier 2 considers the same model used for Tier 1 but uses country-specific EFs. Tier 3 allows inputs, including country-specific EFs and emission estimation models. In this study, the Tier 3 approach was applied to all investigated WWTPs, following Danish national guideline (DNG), which models $\mathrm{CH}_{4}$ emissions by considering two main methane sources: $\mathrm{CH}_{4}$ emissions from the sewer network plus mechanical and biological treatment processes according to plantspecific pollution load, and $\mathrm{CH}_{4}$ emissions from anaerobic digestion according to plant-specific $\mathrm{CH}_{4}$ production (Thomsen, 2016). For a further comparison, IPCC Tier 1 was also applied, as it models biomethane potential according to a default $\mathrm{CH}_{4}$-producing capacity factor and a country-specific organic pollution load per PE. Total $\mathrm{CH}_{4}$ emissions were finally calculated by subtracting plant-specific recalcitrant organic matter remaining in the biosolids and plant-specific $\mathrm{CH}_{4}$ production from biomethane potential.

In order to estimate $\mathrm{N}_{2} \mathrm{O}$ emissions from WWTPs, the IPCC guideline provides only a single emission estimation model based on default EFs that considers plant-specific pollution load expressed as PE. In addition, $\mathrm{N}_{2} \mathrm{O}$ emissions were also estimated following the DNGs, which apply country-specific EFs and plant-specific nitrogen loads. The applied estimation models for $\mathrm{CH}_{4}$ and $\mathrm{N}_{2} \mathrm{O}$ emission estimation are presented in detail in the SI sections $\mathrm{S} 3$ and S4, in which plant-specific data are also reported. 


\section{Results and discussion}

Fig. 2 shows two representative examples of tracer gas simulation of the emission source: The relative concentrations of the target and the tracer gas followed each other across the whole transect. This was checked constantly during the measurements and thus was always the case. If improper source simulation was observed, the configuration of the tracer gas release was changed prior to emission quantification.
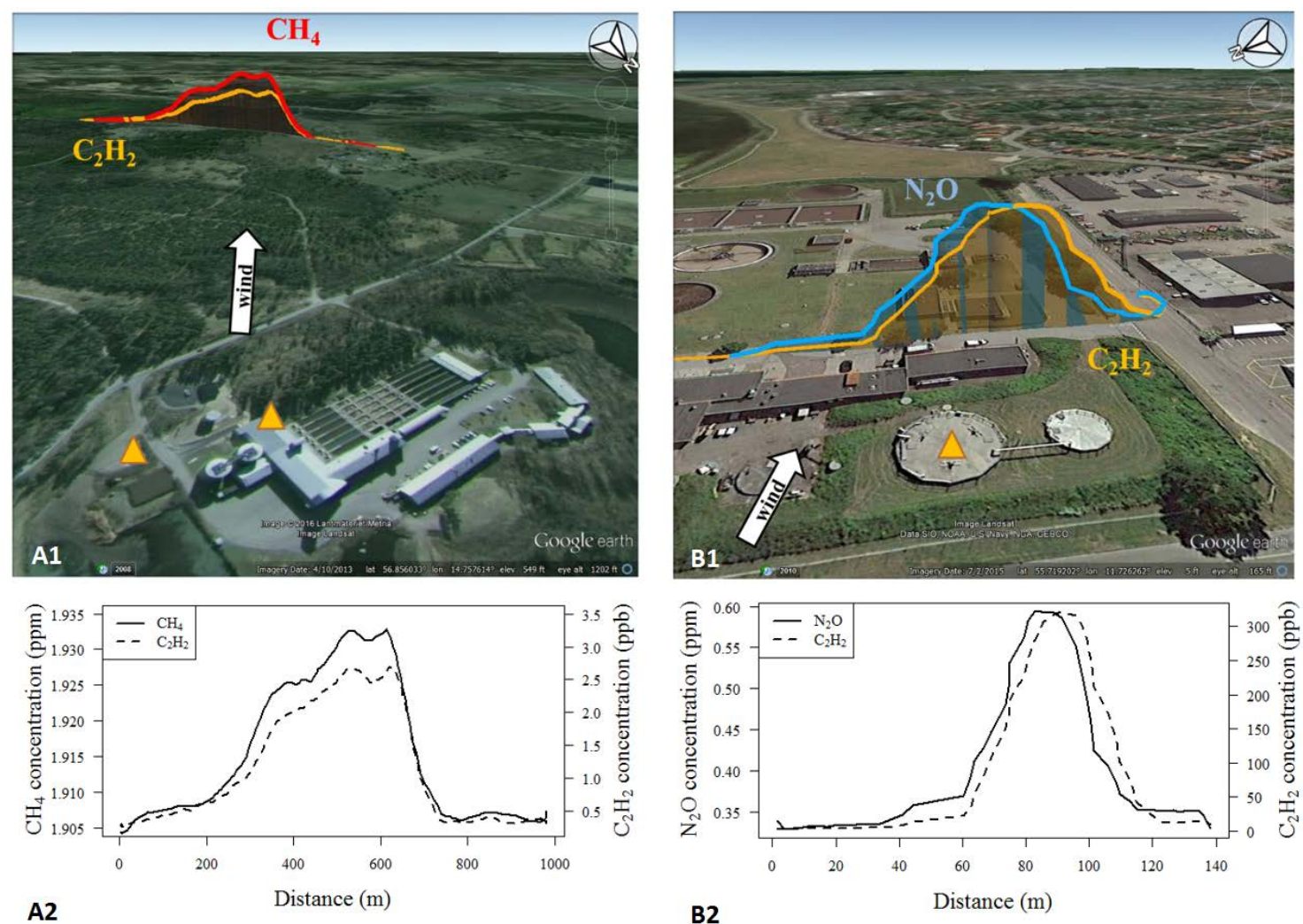

Fig. 2. Examples of downwind plume transects. A) Downwind $\mathrm{CH}_{4}$ and $\mathrm{C}_{2} \mathrm{H}_{2}$ plumes for plant-integrated $\mathrm{CH}_{4}$ emission quantification from the WWTP in Växjö. A1 shows the plume locations on a Google Earth (c) image, while A2 plots plume concentrations, including background along the transect. B) Downwind $\mathrm{N}_{2} \mathrm{O}$ and $\mathrm{C}_{2} \mathrm{H}_{2}$ plumes for $\mathrm{N}_{2} \mathrm{O}$ emission quantification downwind of the reject water treatment unit at the WWTP in Holbæk. B1 shows plume locations on a Google Earth (C) image, while B2 plots concentrations, including background along the transect. Yellow triangles mark tracer release locations. The white arrows define wind direction. 


\subsection{Plant-integrated $\mathrm{CH}_{4}$ emission rates and emission factors}

Plant-integrated $\mathrm{CH}_{4}$ emission rates were between $1.1 \pm 0.1$ and $18.1 \pm 6.3 \mathrm{~kg}$ $\mathrm{CH}_{4} \mathrm{~h}^{-1}$ (average (AV) \pm standard deviation (SD)) and therefore well above detection limits $\left(0.1-5.0 \mathrm{~kg} \mathrm{CH}_{4} \mathrm{~h}^{-1}\right)$ and could be quantified at facilities with very different plant layouts and treatment technologies. The relatively high $\mathrm{CH}_{4}$ emission rate in comparison to the low detection limit of the analytical instrument allowed for downwind detection even at distances greater than $1 \mathrm{~km}$. Where possible, transects were performed over several hours, in order to capture emission trends over time. However, none of the measurement campaigns showed a clear temporal trend for $\mathrm{CH}_{4}$ release.

UTH values for most of the WWTPs were small (<14\%) (Table S8 in SI), suggesting that the measurements were performed at appropriate distances away from the sites to capture all of their $\mathrm{CH}_{4}$ emissions. One exception was Lynetten, where it reached 52\% (during the last two campaigns). Nevertheless, this value did not change the reliability of the results at Lynetten, because UTH estimates the worst-case scenario when the majority of the emissions occur at elevated heights, such as from the occasional venting of anaerobic digesters. During all measurements performed at Lynetten, nothing suggested the occurrence of such venting events: Neither downwind plumes showed sudden changes in $\mathrm{CH}_{4}$ concentrations nor quick pressure drops were recorded in the digesters.

Emission rates from the different plants were compared using EFs. For plants producing biogas, the literature reports $\mathrm{CH}_{4}$ emissions normalized by $\mathrm{CH}_{4}$ production (e.g. $\mathrm{kg} \mathrm{CH} 4$ emitted per $\mathrm{kg} \mathrm{CH}_{4}$ produced), while $\mathrm{CH}_{4}$ emissions from main wastewater treatment reactors are often normalized by organic load into the plant (e.g. $\mathrm{kg} \mathrm{CH}_{4}$ emitted per kg $\mathrm{COD}_{\text {influent }}$ into the plant). Fig. 3A shows both types of EFs for the performed measurement campaigns, thereby allowing analysis of $\mathrm{CH}_{4}$ losses from both an energetic and a treatment capacity perspective. EF values are compiled in Table S8 in SI.

Plant-specific EFs based on the measured plant-integrated $\mathrm{CH}_{4}$ emissions ranged between $1.1 \%$ and $21.3 \%$ as $\mathrm{kg} \mathrm{CH}_{4}\left(\mathrm{~kg} \mathrm{CH}_{4} \text { prod.) }\right)^{-1}$ and between $0.2 \%$ and $3.2 \%$ as $\mathrm{kg} \mathrm{CH}_{4}$ (kg COD influent) ${ }^{-1}$ (Fig. 3A). Little variation in EFs was seen between different measurement campaigns performed at individual plants. Only two exceptions were recorded. At Växjö, very high $\mathrm{CH}_{4}$ emissions were measured during the first measurement campaign compared 
to the two following campaigns (Table S8 in SI). According to the plant operator, a leak at the top of one of the anaerobic digesters was discovered and repaired between the first two campaigns. At Holbæk, the higher EF based on $\mathrm{CH}_{4}$ production was caused by an unusual $70 \%$ lower $\mathrm{CH}_{4}$ production compared to the other campaigns. The lowest EFs were obtained from Lundtofte and Lynetten, which have enclosed sludge, digestate, and biosolids storage facilities and on-site incineration of biosolids, thereby avoiding $\mathrm{CH}_{4}$ emissions from the anaerobic decomposition of organic matter remaining in the stored material. At Holbæk WWTP, final biosolids are transported off-site for treatment at a different facility. However, a higher EF at this plant, in comparison to the other two Danish facilities (Lundtofte and Lynetten), could be explained by the open storage of sludge, digestate, and biosolids and by the use of a combined heat and power engine, which is known to have minor $\mathrm{CH}_{4}$ slippage due to incomplete combustion. At Lundtofte and Lynetten, the generated biogas is fed directly into the local gas grid. The investigated Swedish plants (Källby and Växjö) have biogas upgrading systems, which are known to emit $\mathrm{CH}_{4}$ (Reinelt et al., 2017). Furthermore, both plants store organic material on site-in Källby this applies to sludge, digestate, and biosolids, and in Växjö biosolids are stored outdoors, where material can rest for several months. On-site sludge storage in open basins and biogas upgrading technologies could thus be the reason for the higher EFs obtained from the Swedish WWTPs.

In general, the on-site $\mathrm{CH}_{4}$ screenings supported the notion that the main emitting sources at the five plants were sludge treatment and energy production units, indicated by continuous high-atmospheric $\mathrm{CH}_{4}$ concentrations (e.g. Fig. 1A2). Only in Lundtofte and Lynetten were mechanical pretreatments a relevant $\mathrm{CH}_{4}$ source. $\mathrm{CH}_{4}$ emissions from the main wastewater reactors occurred mainly during aeration and mixing but lasted only for a few seconds. However, the abovementioned qualitative statements should be supported quantitatively by measurements capable of distinguishing between emissions from various process units. 

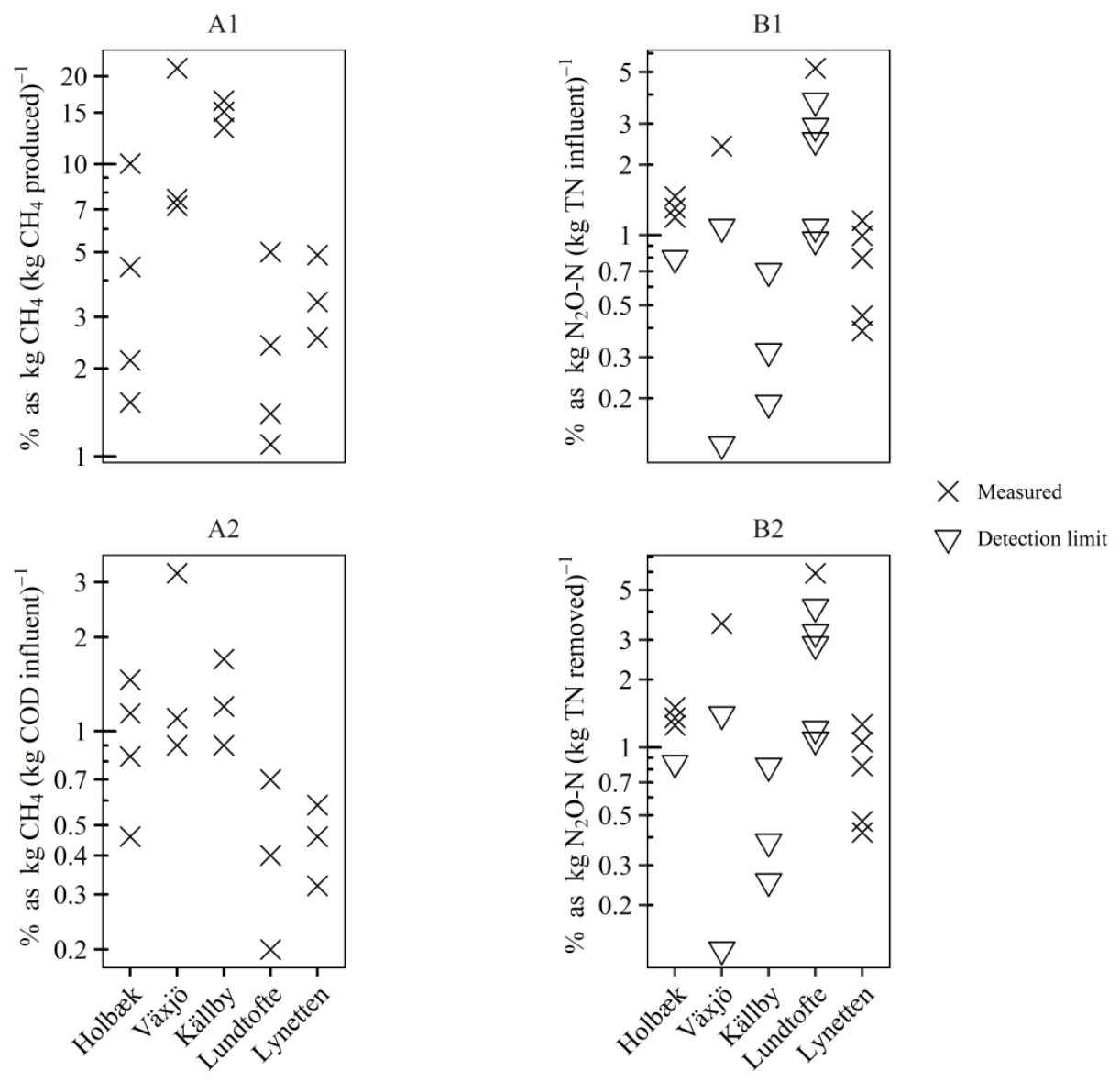

Fig. 3. Comparison of plant-integrated EFs based on emissions measured at five WWTPs. A1 shows $\mathrm{CH}_{4}$ EFs normalized to $\mathrm{CH}_{4}$ production, whereas A2 shows $\mathrm{CH}_{4}$ EFs normalized to organic plant load. $\mathrm{B} 1$ shows $\mathrm{N}_{2} \mathrm{O}$ EFs normalized to the TN load into the plant, whereas B2 shows EFs normalized to TN removed from the plant. 
Fig. 4 and Fig. 5 compare $\mathrm{CH}_{4}$ EFs obtained in this study with EFs reported in the literature and those used in international guidelines for emission reporting (Clean Development Mechanism (CDM), 2012; Thomsen, 2016). $\mathrm{CH}_{4}$ EFs in the literature cover emissions measured at WWTPs as well as those measured at individual biogas plants treating manure, organic household waste, and industrial waste. The latter were included, as there are very few $\mathrm{CH}_{4}$ emission data available from WWTPs and as both kinds of plants use similar process units and technologies. At WWTPs, the $\mathrm{CH}_{4}$ EFs varied between $0.15 \%$ and $32.7 \%$. The lowest $\mathrm{CH}_{4}$ emissions were observed at a Swedish WWTP (Petersson, 2012), which could be due to the fact that the study focused only on emissions from the sludge treatment line and thus did not include potential emissions from the wastewater treatment line. In addition, the emissions were measured by applying point measurements, whereas the study by Yoshida et al. (2014b) and the present study applied remote sensing, which quantifies a site's total $\mathrm{CH}_{4}$ emissions. In general, $\mathrm{CH}_{4} \mathrm{EFs}$ measured at biogas plants tended to be at the lower end of the range of EFs measured at WWTPs in this study. This difference could be because biogas plants treating organic waste earn money selling gas, and thus they have a stronger focus on gas generation and optimization, whereas WWTPs earn money by treating wastewater, albeit this notion cannot be confirmed. The CDM guideline does not offer $\mathrm{CH}_{4} \mathrm{EFs}$ specific to wastewater treatment but only gives default EFs (ranging from 2.8 to $10 \%$ of produced $\mathrm{CH}_{4}$ depending on the type of anaerobic digester) for anaerobic digestion of organic material in general (e.g. manure, food waste, sewage sludge, etc.) (CDM, 2012). In general, the default CDM EFs tended to be higher in comparison to EFs based on measurements at biogas plants (Fig. 4). The CDM EFs were within the rather broad range of EFs measured at WWTPs based on whole-site $\mathrm{CH}_{4}$ emissions. There was, however, no relationship between EFs based on measurements and the specific type of anaerobic digesters at the individual plants. The EF used in the DNG (1.3\% of produced $\mathrm{CH}_{4}$ (Thomsen, 2016)) was, in most cases, lower than the EFs obtained based on measurements. 

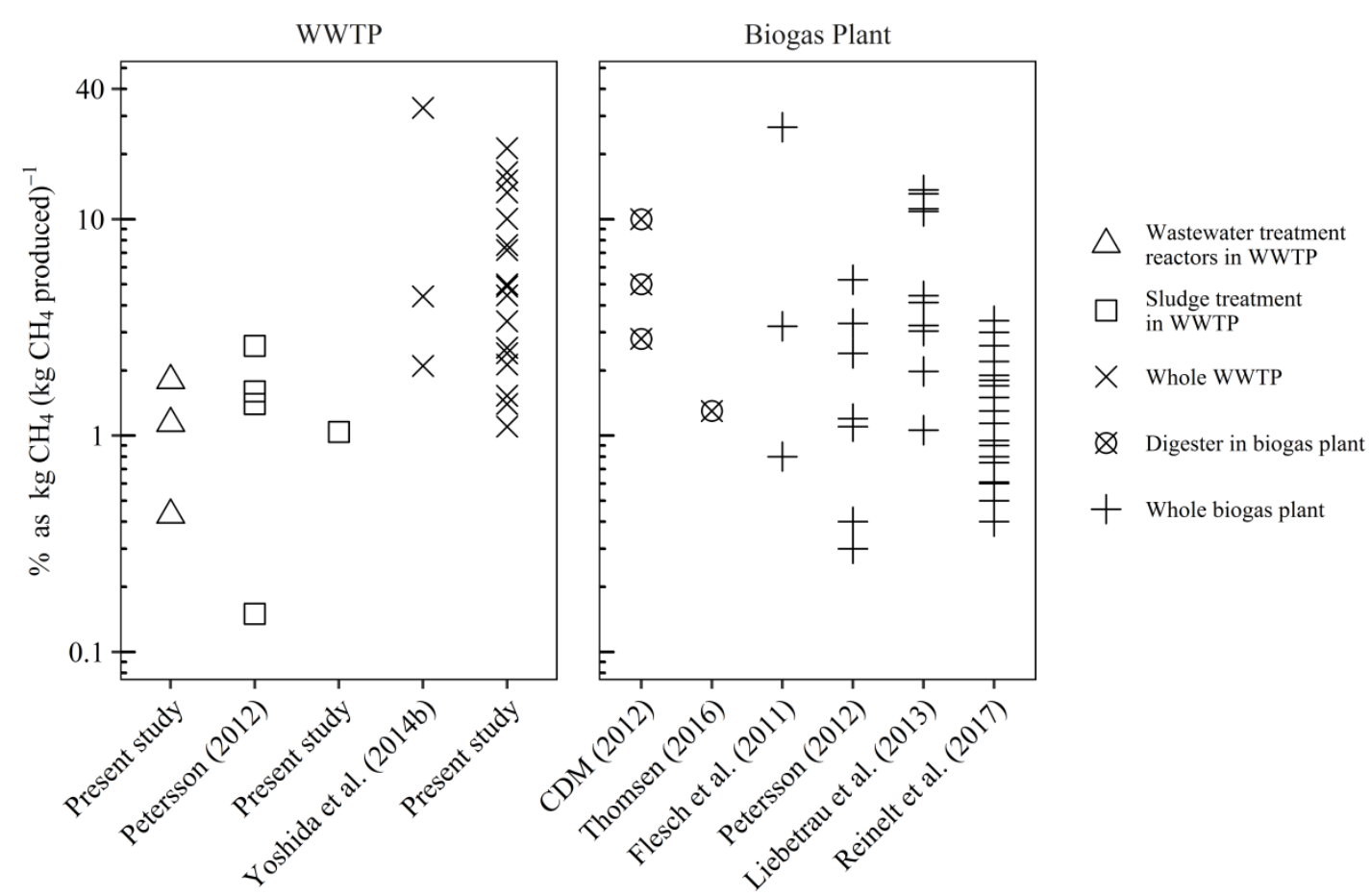

Fig. 4. Literature comparison of $\mathrm{CH}_{4}$ EFs expressed in percentage as $\mathrm{kg} \mathrm{CH}_{4}\left(\mathrm{CH}_{4} \text { prod.) }\right)^{-1}$. Note that all the studies used point measurements, with the exception of Flesch et al. (2011), Yoshida et al. (2014b), Reinelt et al. (2017), and the present study, all of which used remote measurement approaches.

Fig. 5 shows EFs expressed in percentage of $\mathrm{kg} \mathrm{CH}_{4}$ (COD influent) ${ }^{-1}$ reported for WWTPs in the literature. $\mathrm{CH}_{4}$ EFs were in the range $0.016 \%$ to $9.08 \%$. In general, EFs considering $\mathrm{CH}_{4}$ emissions from the wastewater treatment line and the sludge treatment line were comparable and lower than EFs based on whole-site emission measurements, respectively. This was also the case at Lynetten where it was possible to separate and quantify the $\mathrm{CH}_{4}$ emissions from the wastewater treatment line and the sludge treatment (Fig. 4 and 5) on an individual basis. This distinction was only possible at Lynetten (Table S8) and was due to the plant layout with some processes being rather far from each other. Using specific wind directions and measuring distances, the plumes from the wastewater treatment line and sludge treatment could be separated. Overall, the compilation of EFs in the literature shows that both the wastewater treatment line and its sludge treatment counterpart are associated with $\mathrm{CH}_{4}$ emissions and contribute to the site's total emissions. 


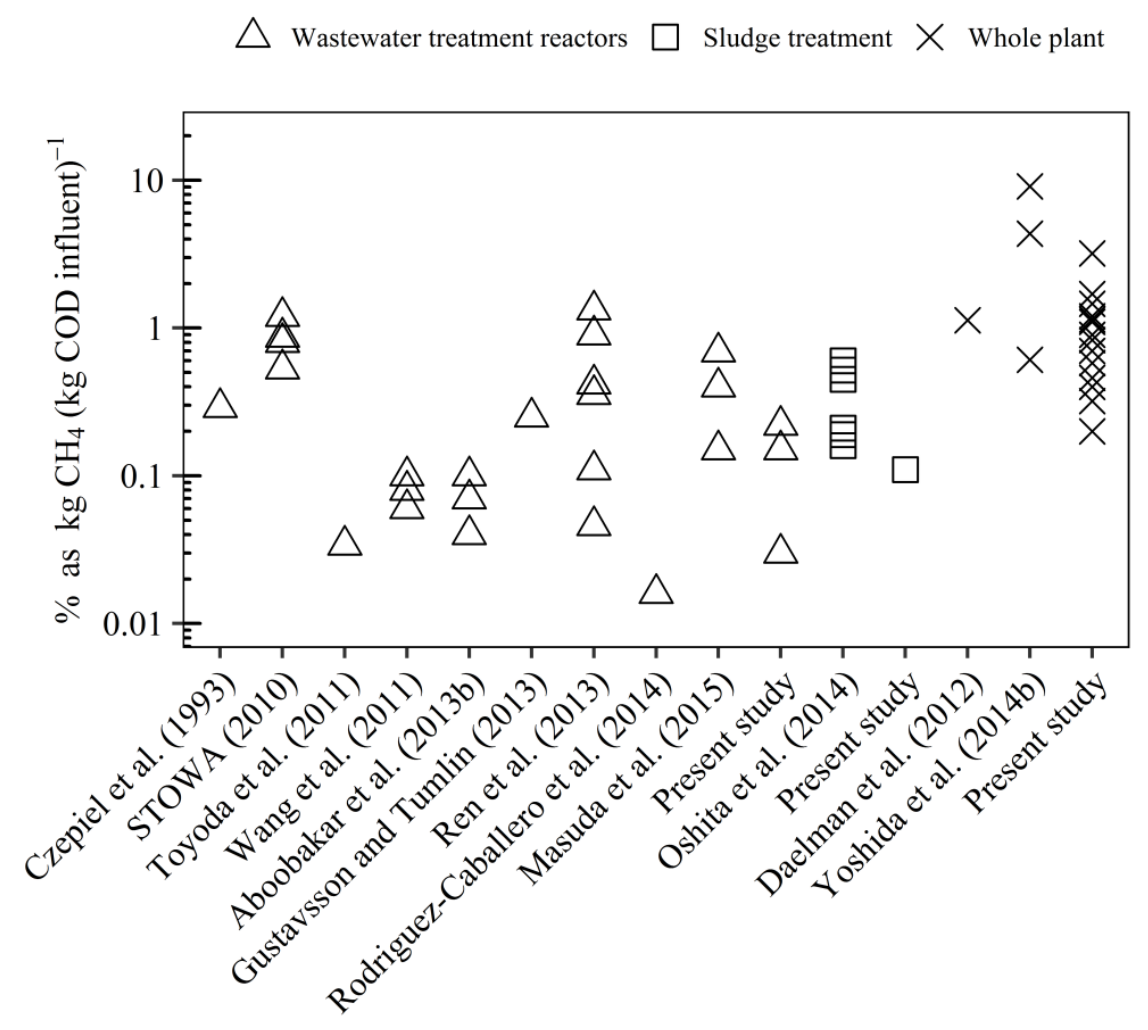

Fig. 5. Literature comparison of $\mathrm{CH}_{4}$ EFs expressed as $\mathrm{kg} \mathrm{CH}_{4}$ (COD influent) ${ }^{-1}$ (\%). All studies refer to WWTPs. With the exception of the present study and Yoshida et al. (2014b), which used remote measurement approaches, all emission rates were obtained from point measurements.

Fig. 6A shows a comparison of the measured $\mathrm{CH}_{4}$ emission rates and estimated emission rates, following the IPCC Tier 1 and the DNG (calculations are shown in SI, section $\mathrm{S} 3$ ). In all cases, estimated $\mathrm{CH}_{4}$ emissions following the IPCC Tier 1 were significantly higher than the measured emissions (between five and 29 times higher, when comparing average annual emissions) (Fig. $6 \mathrm{~A}$ ). These higher $\mathrm{CH}_{4}$ emissions could be caused by an overestimation of the actual biomethane potential of the influent wastewater in the IPCC estimation model (Eq. S7 in SI), as this value is the only input dataset that is not plantspecific in the IPCC Tier 1 model. On the contrary, the estimated $\mathrm{CH}_{4}$ emissions following the DNG were lower compared to the measured emissions (up to nine times) (Fig. 6A). The Danish guideline considers $\mathrm{CH}_{4}$ emissions from sewer systems, mechanical and biological treatment, and from anaerobic digestion. Following this guideline, a significant part of the $\mathrm{CH}_{4}$ was emitted from the sewer system and mechanical and biological treatment (from 20 to 
$40 \%$ of the total estimated $\mathrm{CH}_{4}$ emissions) in comparison to anaerobic digestion (Table S2 in the SI). At Holbæk, this share was even higher (up to 86\%), because the plant, in proportion to its pollution load, produced from seven to 14 times less $\mathrm{CH}_{4}$ than the other WWTPs. On-site $\mathrm{CH}_{4}$ screenings performed at the investigated sites indicated $\mathrm{CH}_{4}$ emissions from biological treatment reactors, especially during aeration (e.g. Fig. 1A2). Only at Lundtofte and Lynetten were mechanical pretreatments a relevant $\mathrm{CH}_{4}$ source. However, in general, atmospheric $\mathrm{CH}_{4}$ concentrations were relatively low in comparison to concentrations measured close to or downwind of the sludge treatment units (e.g. Fig. 1A2). It is thus most likely that the EF of $1.3 \%$ applied while estimating $\mathrm{CH}_{4}$ from anaerobic digestion actually underestimates authentic $\mathrm{CH}_{4}$ emissions from the anaerobic digesters. The best comparisons between measured and estimated emissions were seen for Lundtofte and Lynetten, where the two results were comparable (Fig. 6A), which is most likely because these sites have on-site incineration and thus no biosolid storage. At the other three sites, the measured emission was on average about seven to eight times higher than the DNG estimation, which most likely was caused by the fact that the guideline does not consider emissions from the on-site storage of organic materials but only losses occurring from anaerobic digesters. On-site $\mathrm{CH}_{4}$ screenings at all three sites showed elevated methane concentrations close to stockpiles of organic material, as well as storage of sludge and digestate, indicating that these units potentially were significant $\mathrm{CH}_{4}$ sources. 

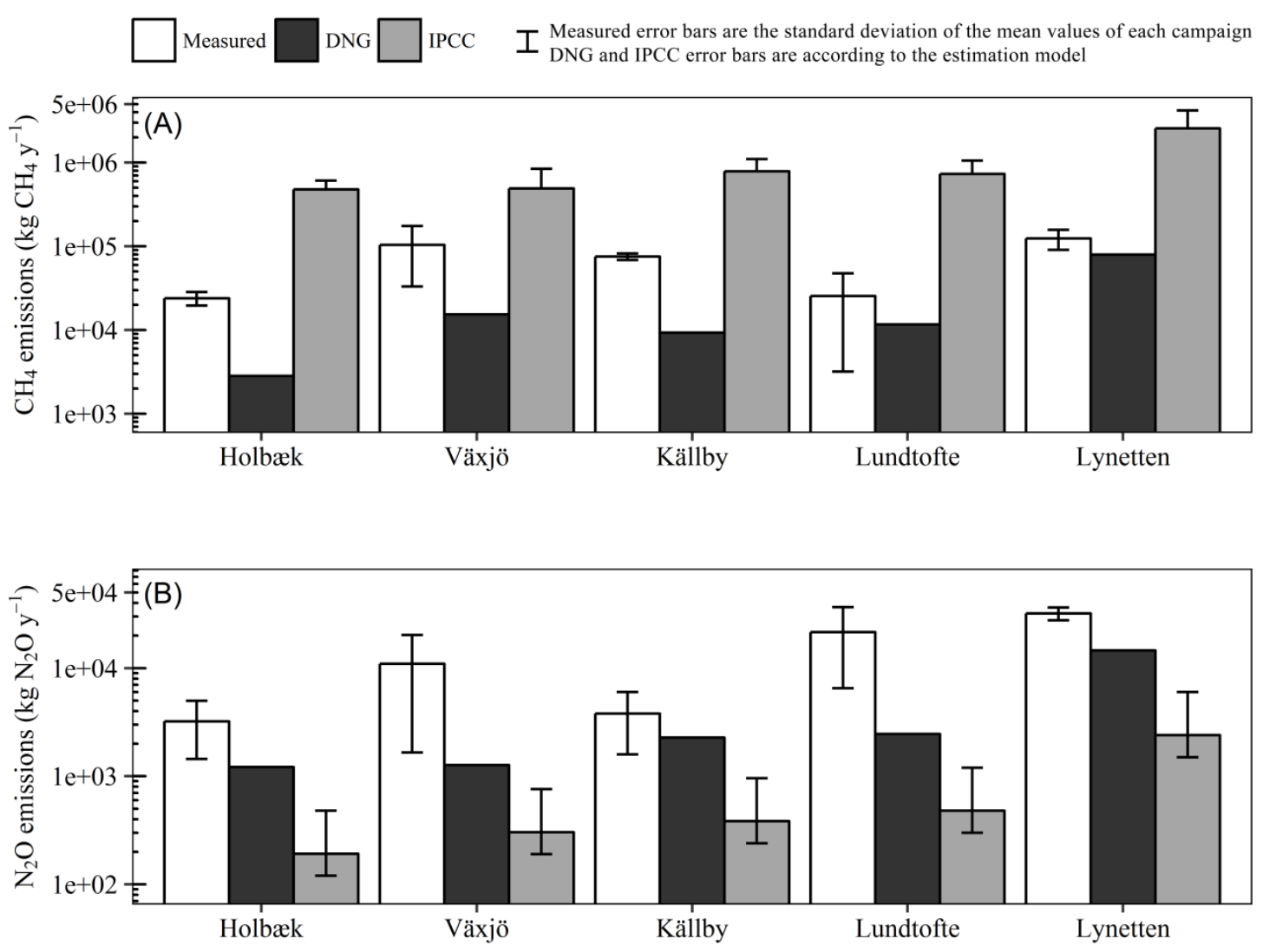

Fig. 6. Comparison of measured $\mathrm{CH}_{4}(\mathrm{~A})$ and $\mathrm{N}_{2} \mathrm{O}$ (B) emission rates and estimated emission rates following the Danish national guideline (DNG) and IPCC Tier 1 guideline. $\mathrm{N}_{2} \mathrm{O}$ emissions measured at Växjö, Källby, and Lundtofte are based on detection limits. 


\subsection{Plant-integrated $\mathrm{N}_{2} \mathrm{O}$ emission rates and emission factors}

$\mathrm{N}_{2} \mathrm{O}$ emission rates from the WWTPs were between $0.4 \pm 0.1$ and $5.7 \pm 2.4$ $\mathrm{kg} \mathrm{N}_{2} \mathrm{O} \mathrm{h}{ }^{-1}(\mathrm{AV} \pm \mathrm{SD})$, or below the detection limit $\left(0.1-3.1 \mathrm{~kg} \mathrm{~N}_{2} \mathrm{O} \mathrm{h}{ }^{-1}\right)$. Only at one of the plants (Källby) were $\mathrm{N}_{2} \mathrm{O}$ emissions always below the detection limit (Fig. 3B). Despite measurement periods of up to 3 hours, no significant temporal $\mathrm{N}_{2} \mathrm{O}$ emission trends were identified. On-site screenings showed $\mathrm{N}_{2} \mathrm{O}$ emissions from the wastewater treatment reactors mainly during aeration and mixing (e.g. Fig. 1A2). Significant $\mathrm{N}_{2} \mathrm{O}$ emission dynamics from biological nitrogen removal reactors have been observed in previous studies, where $\mathrm{N}_{2} \mathrm{O}$ is often emitted during aeration, thereby showing spatial and temporal variability across of the reactor surface (Aboobakar et al., 2013a; Law et al., 2012). In the referenced studies, $\mathrm{N}_{2} \mathrm{O}$ emissions were measured at individual reactors, using flux chambers. In this study, plant-integrated $\mathrm{N}_{2} \mathrm{O}$ emissions were measured, which implied that the measured emission was averaged over aerated and non-aerated treatment stages or units, which could explain why no emission dynamics were seen within individual measurement campaigns. One exception was Holbæk, where the emission rates dropped below the detection limit when aeration stopped in the deammonification process for treating reject water. However, at this plant, the reject water treatment unit was the main $\mathrm{N}_{2} \mathrm{O}$-emitting source, and $\mathrm{N}_{2} \mathrm{O}$ emissions from the other wastewater treatment units were below detection levels.

Plant-specific EFs were determined based on measured $\mathrm{N}_{2} \mathrm{O}$ emission rates and the recorded TN influent of the plant (percentage as $\mathrm{kg} \mathrm{N}_{2} \mathrm{O}-\mathrm{N}(\mathrm{kg} T \mathrm{~N}$ influent $)^{-1}$ ). In addition, EFs were calculated based on the nitrogen removal of the different WWTPs (percentage as $\mathrm{kg} \mathrm{N}_{2} \mathrm{O}-\mathrm{N}$ (kg TN removed) ${ }^{-1}$ ). EFs ranged from $<0.1 \%$ to $5.2 \%$ as $\mathrm{kg} \mathrm{N}_{2} \mathrm{O}-\mathrm{N}$ (kg TN influent) $)^{-1}$ or from $<0.1 \%$ to $5.9 \%$ as $\mathrm{kg} \mathrm{N}_{2} \mathrm{O}-\mathrm{N}$ (kg TN removed) ${ }^{-1}$ (Fig. 3B).

Fig. 7 shows EFs for wastewater treatment reported in the literature and normalized to TN influent. Most studies have focused on measuring $\mathrm{N}_{2} \mathrm{O}$ emissions from wastewater treatment reactors, and EFs vary over several orders of magnitude $\left(0.001 \%\right.$ to $9.29 \%$ as $\mathrm{kg} \mathrm{N}_{2} \mathrm{O}-\mathrm{N}$ (TN influent) $\left.{ }^{-1}\right) . \mathrm{N}_{2} \mathrm{O}$ emissions from reject water treatment tend to be at the higher end of the EFs range for wastewater treatment reactors (Gustavsson and la Cour Jansen, 2011; Kampschreur et al., 2008; Schaubroeck et al., 2015), whereas EFs for sludge management (Oshita et al., 2014) tend to be at the lower end (Fig. 7). Wholesite $\mathrm{N}_{2} \mathrm{O}$ EFs measured using remote sensing approaches (Present study and 
Yoshida et al., (2014b)) provided $\mathrm{N}_{2} \mathrm{O}$ EFs in the upper echelon of the literature range.

Even though fewer studies report EFs in percentage as $\mathrm{kg} \mathrm{N}_{2} \mathrm{O}-\mathrm{N}$ (TN removed $)^{-1}$ (Fig. S1 in SI), a very similar emission pattern is observed with EFs from wastewater treatment reactors, varying between $0.01 \%$ and $5.9 \%$, and relatively high EFs from reject water treatment and whole-site emissions.

Fig. 6B compares measured $\mathrm{N}_{2} \mathrm{O}$ emission rates with emission rates estimated following the DNG and the IPCC guidelines (calculations are shown in SI, section S4). For all WWTPs, the measured $\mathrm{N}_{2} \mathrm{O}$ emissions were always higher than those estimated using the IPCC Tier 1 (up to 45 times) and the DNG (up to nine times) (Fig. 6B). In general, the IPCC assumes that $\mathrm{N}_{2} \mathrm{O}$ emissions from wastewater treatment are minor and only need to be estimated from WWTPs operating advanced nitrification and denitrification processes. For advanced treatment plants, the IPCC nevertheless adopts a relatively low EF (2 to $8 \mathrm{~g} \mathrm{~N}_{2} \mathrm{O} \mathrm{PE}{ }^{-1}$ year $^{-1}$ corresponding to $0.01 \%$ to $0.06 \%$ as $\mathrm{kg} \mathrm{N}_{2} \mathrm{O}-\mathrm{N}$ (kg TN influent) $)^{-1}$ ) based on a study carried out on a WWTP without nitrogen removal (Czepiel et al., 1995). In comparison, the DNG provides a higher default $\mathrm{EF}$ of $0.32 \%$ as $\mathrm{kg} \mathrm{N}_{2} \mathrm{O}-\mathrm{N}$ (kg TN influent) ${ }^{-1}$, corresponding to $24 \mathrm{~g}$ $\mathrm{N}_{2} \mathrm{O}$ PE$^{-1}$ year $^{-1}$ (Thomsen, 2016), which for many of the studied sites was lower than the measured EFs $\left(<0.1 \%\right.$ to $5.2 \%$ as $\mathrm{kg} \mathrm{N}_{2} \mathrm{O}-\mathrm{N}$ (kg TN influent) ${ }^{-}$ $\left.{ }^{1}\right)$. 
$\square$ Sludge treatment $\times$ Whole plant

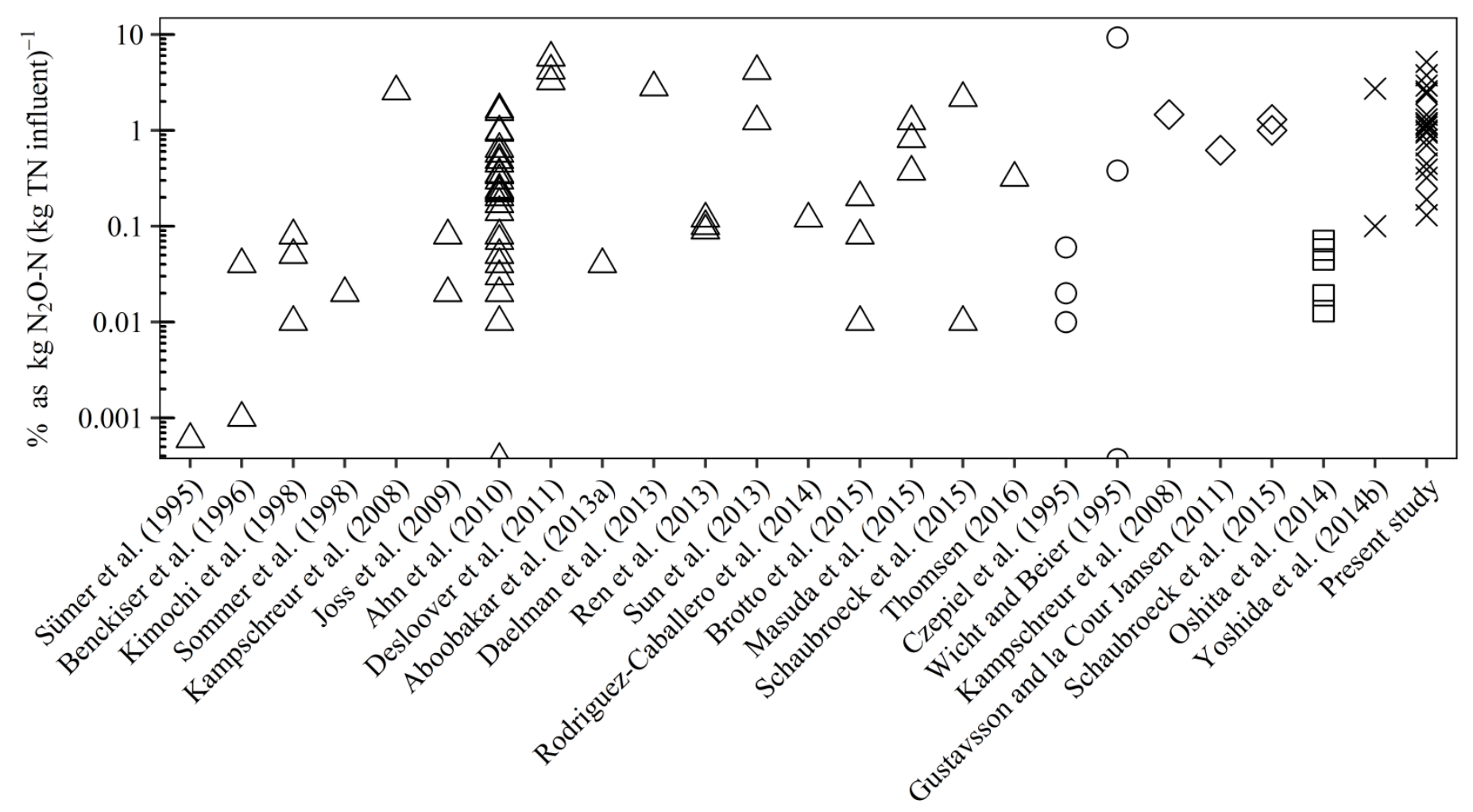

Fig. 7. Literature comparison of $\mathrm{N}_{2} \mathrm{O}$ EFs expressed in percentage as $\mathrm{kg} \mathrm{N}_{2} \mathrm{O}-\mathrm{N}$ (TN influent) ${ }^{-1}$. With the exception of the present study and Yoshida et al. (2014b), which used remote measurement approaches, all values were obtained from point measurements. Data are grouped by source and study in chronological order. 


\section{Conclusions and perspectives}

Plant-integrated emissions rates were measured by remote sensing combining a controlled release of tracer gas from the plant with concentration measurements downwind of the plant. In addition, the mobile analytical instrument was used for site-screening and identification of important on-site emission sources. Plant-integrated $\mathrm{CH}_{4}$ and $\mathrm{N}_{2} \mathrm{O}$ emission quantifications were performed at five Scandinavian wastewater treatment plants (WWTPs), resulting in emission factors (EFs) in the upper range of EFs reported in the literature and default EFs applied in international guidelines. This is most likely a result of the measurement approach applied in this study, which quantifies total emissions from sites, whereas most of the studies reported in the literature, to date, have focused on the emission quantification of individual treatment units at WWTPs, especially emissions from the wastewater treatment reactors and reject water treatment. The main $\mathrm{CH}_{4}$ emitting sources at the five plants were sludge treatment and energy production units. The lowest $\mathrm{CH}_{4} \mathrm{EFs}$ were obtained at plants having enclosed sludge treatment and storage units. For the five Scandinavian WWTPs included in this study, $\mathrm{CH}_{4}$ and $\mathrm{N}_{2} \mathrm{O}$ emission rates were site-specific, and currently applied default EFs used for national emission reporting were inaccurate for site-specific emission reporting and tended to underestimate greenhouse gas (GHG) emissions.

The advantage of measuring emissions using remote sensing approaches is that they include the emissions from all on-site sources and thus reduce the potential uncertainty related to overlooking individual on-site emission sources, which could lead to an underestimation of the plant's total emission. Plant-integrated emission rates are needed for emission reporting, environmental assessments, and documentation of GHG emission mitigation actions. On-site measurement methods, however, are very important for identifying leakages and quantifying emissions from specific unit processes in order to optimize the daily operation of the plant. 


\section{Acknowledgements}

This work was funded in part by the Innovation Fund Denmark (IFD) (Project LaGAS, File No. 0603-00523B) and Veolia Water Technologies (Krüger, AnoxKaldnes, The Veolia Group). Support from the wastewater utilities (Biofos, DK; VA SYD, SE; Lyngby-Taarbæk forsyning, DK; FORS A/S, DK; Växjö, SE) and Unisense Environment, DK, and Fluxsense AB, SE is acknowledged. The authors thank plant managers for their assistance during the whole study and the staff of the wastewater treatment plants for facilitating the measurements.

\section{Supporting information}

The supporting information (SI) provides further details on the performed measurement campaigns and measured emission rates. More detailed descriptions of guidelines used for national emission reporting and estimated emissions following these guidelines are included. 


\section{References}

Aboobakar, A., Cartmell, E., Stephenson, T., Jones, M., Vale, P., Dotro, G., 2013a. Nitrous oxide emissions and dissolved oxygen profiling in a fullscale nitrifying activated sludge treatment plant. Water Res. 47, 524534. doi:10.1016/j.watres.2012.10.004

Aboobakar, A., Jones, M., Vale, P., Cartmell, E., Dotro, G., 2013b. Methane emissions from aerated zones in a full-scale nitrifying activated sludge treatment plant. Water, Air, Soil Pollut. 225, 1814 (1-10). doi:10.1007/s11270-013-1814-8

Ahn, J.H., Kim, S., Park, H., Rahm, B., Pagilla, K., Chandran, K., 2010. N $2 \mathrm{O}$ emissions from activated sludge processes, 2008-2009: results of a national monitoring survey in the United States. Environ. Sci. Technol. 44, 4505-11. doi:10.1021/es903845y

Benckiser, G., Eilts, R., Linn, A., Lorch, H.-J., Sümer, E., Weiske, A., Wenzhöfer, F., 1996. $\mathrm{N}_{2} \mathrm{O}$ emissions from different cropping systems and from aerated, nitrifying and denitrifying tanks of a municipal waste water treatment plant. Biol. Fertil. Soils 23, 257-265. doi:10.1007/BF00335953

Briggs, G.A., 1974. Diffusion Estimation for Small Emissions, in Environmental Research Laboratories Air Resources Atmospheric Turbulence and Diffusion Laboratory 1973 Annual Report, USAEC Report ATDL106, National Oceanic and Atmospheric Administration, Washington, DC.

Brotto, A.C., Kligerman, D.C., Andrade, S. a, Ribeiro, R.P., Oliveira, J.L.M., Chandran, K., de Mello, W.Z., 2015. Factors controlling nitrous oxide emissions from a full-scale activated sludge system in the tropics. Environ. Sci. Pollut. Res. 22, 11840-11849. doi:10.1007/s11356-015-4467-x

CDM, 2012. The Clean Development Mechanism - Methodological Tool: Project and Leakage Emission from Anaerobic Digesters v.01.0.0. Last accessed on April 22 ${ }^{\text {nd }}$, 2017. Available at: http://cdm.unfccc.int/methodologies/PAmethodologies/tools/am-tool14-v1.pdf

Czepiel, P., Crill, P., Harriss, R., 1995. Nitrous oxide emissions from municipal wastewater treatment. Environ. Sci. Technol. 29, 2352-2356. doi:10.1021/es00009a030

Czepiel, P., Crill, P., Harriss, R., 1993. Methane emissions from municipal wastewater treatment processes. Environ. Sci. Technol. 27, 2472-2477. doi:10.1021/es00048a025 
Daelman, M.R.J., van Voorthuizen, E.M., van Dongen, L.G.J.M., Volcke, E.I.P., van Loosdrecht, M.C.M., 2013. Methane and nitrous oxide emissions from municipal wastewater treatment - results from a long-term study. Water Sci. Technol. 67, 2350-2355. doi:10.2166/wst.2013.109

Daelman, M.R.J., van Voorthuizen, E.M., van Dongen, U.G.J.M., Volcke, E.I.P., van Loosdrecht, M.C.M., 2012. Methane emission during municipal wastewater treatment. Water Res. 46, 3657-3670. doi:10.1016/j.watres.2012.04.024

Desloover, J., De Clippeleir, H., Boeckx, P., Du Laing, G., Colsen, J., Verstraete, W., Vlaeminck, S.E., 2011. Floc-based sequential partial nitritation and anammox at full scale with contrasting $\mathrm{N}_{2} \mathrm{O}$ emissions. Water Res. 45, 2811-2821. doi:10.1016/j.watres.2011.02.028

Doorn, M.R.J., Towprayoon, S., Manso Vieira, S.M., Irving, W., Palmer, C., Pipatti, R., Wang, C., 2006. IPCC 2006, 2006 IPCC Guidelines for National Greenhouse Gas Inventories, Prepared by the National Greenhouse Gas Inventories Programme - Volume 5: Waste. Hayama, Japan.

EPA, 2016. Danish Environmental Protection Agency website last accessed on April 22 ${ }^{\text {nd }}$, 2017. Available at: http://mst.dk/virksomhedmyndighed/affald/deponering/biocover-tilskudsordning/afrapporteringog-dokumentationskrav/

Flesch, T.K., Desjardins, R.L., Worth, D., 2011. Fugitive methane emissions from an agricultural biodigester. Biomass and Bioenergy 35, 39273935. doi:10.1016/j.biombioe.2011.06.009

Gustavsson, D.J.I., la Cour Jansen, J., 2011. Dynamics of nitrogen oxides emission from a full-scale sludge liquor treatment plant with nitritation. Water Sci. Technol. 63, 2838-2845. doi:10.2166/wst.2011.487

Gustavsson, D.J.I., Tumlin, S., 2013. Carbon footprints of Scandinavian wastewater treatment plants. Water Sci. Technol. 68, 887-893. doi:10.2166/wst.2013.318

Jensen, M.B., Møller, J., Mønster, J., Scheutz, C., 2017. Quantification of greenhouse gas emissions from a biological waste treatment facility. Waste Manag. https://doi.org/10.1016/j.wasman.2017.05.033

Joss, A., Salzgeber, D., Eugster, J., König, R., Rottermann, K., Burger, S., Fabijan, P., Leumann, S., Mohn, J., Siegrist, H., 2009. Full-scale nitrogen removal from digester liquid with partial nitritation and anammox in one SBR. Environ. Sci. Technol. 43, 5301-5306.

Kampschreur, M.J., Temmink, H., Kleerebezem, R., Jetten, M.S.M., van Loosdrecht, M.C.M., 2009. Nitrous oxide emission during wastewater treatment. Water Res. 43, 4093-4103. doi:10.1016/j.watres.2009.03.001 
Kampschreur, M.J., van der Star, W.R.L., Wielders, H.A., Mulder, J.W., Jetten, M.S.M., van Loosdrecht, M.C.M., 2008. Dynamics of nitric oxide and nitrous oxide emission during full-scale reject water treatment. Water Res. 42, 812-826. doi:10.1016/j.watres.2007.08.022

Kimochi, Y., Inamori, Y., Mizuochi, M., Xu, K.Q., Matsumura, M., 1998. Nitrogen removal and $\mathrm{N}_{2} \mathrm{O}$ emission in a full-scale domestic wastewater treatment plant with intermittent aeration. J. Ferment. Bioeng. 86, 202206. doi:10.1016/S0922-338X(98)80114-1

Law, Y., Ye, L., Pan, Y., Yuan, Z., 2012. Nitrous oxide emissions from wastewater treatment processes. Philos. Trans. R. Soc. Lond. B. Biol. Sci. 367, 1265-1277. doi:10.1098/rstb.2011.0317

Liebetrau, J., Reinelt, T., Clemens, J., Hafermann, C., Friehe, J., Weiland, P., 2013. Analysis of greenhouse gas emissions from 10 biogas plants within the agricultural sector. Water Sci. Technol. 67, 1370-1379. doi:10.2166/wst.2013.005

Logan, J.A., Prather, M.J., Wofsy, S.C., McElroy, M.B., 1981. Tropospheric chemistry: a global perspective. J. Geophys. Res. 86, 7210-7254.

Masuda, S., Suzuki, S., Sano, I., Li, Y.-Y., Nishimura, O., 2015. The seasonal variation of emission of greenhouse gases from a full-scale sewage treatment plant. Chemosphere 140, 167-173. doi:10.1016/j.chemosphere.2014.09.042

Mønster, J., Samuelsson, J., Kjeldsen, P., Rella, C.W., Scheutz, C., 2014. Quantifying methane emission from fugitive sources by combining tracer release and downwind measurements - a sensitivity analysis based on multiple field surveys. Waste Manag. 34, 1416-1428. doi:10.1016/j.wasman.2014.03.025

Mønster, J., Samuelsson, J., Kjeldsen, P., Scheutz, C., 2015. Quantification of methane emissions from 15 Danish landfills using the mobile tracer dispersion method. Waste Manag. 35, 177-186. doi:10.1016/j.wasman.2014.09.006

Oshita, K., Okumura, T., Takaoka, M., Fujimori, T., Appels, L., Dewil, R., 2014. Methane and nitrous oxide emissions following anaerobic digestion of sludge in Japanese sewage treatment facilities. Bioresour. Technol. 171, 175-181. doi:10.1016/j.biortech.2014.08.081

Pasquill, F., 1974. Atmospheric Diffusion, Second Edi. ed. Wiley, New York.

Petersson, A., 2012. The Swedish Voluntary system for control of methane emissions. Last accessed on April 22 ${ }^{\text {nd }}$, 2017. Available at: http://task37.ieabioenergy.com/case-studies.html?file=files/datenredaktion/download/case-studies/Case\%20Study\%20Sweden.pdf. 
Reinelt, T., Delre, A., Westerkamp, T., Holmgren, M.A., Liebetrau, J., Scheutz, C., 2017. Comparative use of different emission measurement approaches to determine methane emissions from a biogas plant. Waste Manag. In press. https://doi.org/10.1016/j.wasman.2017.05.053

Reinelt, T., Liebetrau, J., Nelles, M., Biomasseforschungszentrum, D., 2015. Operational methane emissions from pressure relief vents on two agricultural biogas plants, in: International Conference on Solid Waste. Hong Kong.

Ren, Y.G., Wang, J.H., Li, H.F., Zhang, J., Qi, P.Y., Hu, Z., 2013. Nitrous oxide and methane emissions from different treatment processes in fullscale municipal wastewater treatment plants. Environ. Technol. 34, 2917-2927. doi:10.1080/09593330.2012.696717

Rodriguez-Caballero, A., Aymerich, I., Poch, M., Pijuan, M., 2014. Evaluation of process conditions triggering emissions of green-house gases from a biological wastewater treatment system. Sci. Total Environ. 493, 384-391. doi:10.1016/j.scitotenv.2014.06.015

Schaubroeck, T., De Clippeleir, H., Weissenbacher, N., Dewulf, J., Boeckx, P., Vlaeminck, S.E., Wett, B., 2015. Environmental sustainability of an energy self-sufficient sewage treatment plant: Improvements through DEMON and co-digestion. Water Res. 74, 166-79. doi:10.1016/j.watres.2015.02.013

Scheutz, C., Samuelsson, J., Fredenslund, a M., Kjeldsen, P., 2011. Quantification of multiple methane emission sources at landfills using a double tracer technique. Waste Manag. 31, 1009-1017. doi:10.1016/j.wasman.2011.01.015

Shrivastava, A., Gupta, V., 2011. Methods for the determination of limit of detection and limit of quantitation of the analytical methods. Chronicles Young Sci. 2, 21-25. doi:10.4103/2229-5186.79345

Sommer, J., Ciplak, G., Linn, A., Sumer, E., Benckiser, G., Ottow, J., 1998. Quantification of emitted and retained $\mathrm{N}_{2} \mathrm{O}$ in a municipal waste water treatment plant with activated sludge and nitrifying-denitrifying units. Agribiol. Res. Fur Agrarbiol. Agrik. Okol. 51, 59-73.

Stocker, T.F., Qin, D., Plattner, G.-K., Tignor, M., Allen, S.K., Boschung, J., Nauels, A., Xia, Y., Bex, V., Midgley, P.M., (eds.), 2013. IPCC, 2013: Climate Change 2013: The Physical Science Basis. Contribution of Working Group I to the Fifth Assessment Report of the Intergovernmental Panel on Climate Change. Cambridge, United Kingdom.

STOWA, 2010. Emissies van broeikasgassen van RWZI's. Amersfoort, The Netherlands. In Daelman et al. (2012). 
Sümer, E., Weiske, A., Benckiser, G., Ottow, J.C.G., 1995. Influence of environmental conditions on the amount of $\mathrm{N}_{2} \mathrm{O}$ released from activated sludge in a domestic waste water treatment plant. Experientia 51, 419422.

Sun, S., Cheng, X., Li, S., Qi, F., Liu, Y., Sun, D., 2013. $\mathrm{N}_{2} \mathrm{O}$ emission from full-scale urban wastewater treatment plants: a comparison between $\mathrm{A}(2) \mathrm{O}$ and SBR. Water Sci. Technol. 67, 1887-1893. doi:10.2166/wst.2013.066

Thomsen, M., 2016. Wastewater treatment and discharge - Scientific Report from DCE - Danish Centre for Environment and Energy.

Toyoda, S., Suzuki, Y., Hattori, S., Yamada, K., Fujii, A., Yoshida, N., Kouno, R., Murayama, K., Shiomi, H., 2011. Isotopomer analysis of production and consumption mechanisms of $\mathrm{N}_{2} \mathrm{O}$ and $\mathrm{CH}_{4}$ in an advanced wastewater treatment system. Environ. Sci. Technol. 45, 917-922. doi:10.1021/es102985u

Wang, J., Zhang, J., Xie, H., Qi, P., Ren, Y., Hu, Z., 2011. Methane emissions from a full-scale $\mathrm{A} / \mathrm{A} / \mathrm{O}$ wastewater treatment plant. Bioresour. Technol. 102, 5479-5485. doi:10.1016/j.biortech.2010.10.090

Wicht, H., Beier, M., 1995. $\mathrm{N}_{2} \mathrm{O}$ emission aus nitrifizierenden und denitrificierenden Kläranlagen. Korrespondenz Abwasser 42, 404-406-413.

Yoshida, H., Clavreul, J., Scheutz, C., Christensen, T.H., 2014a. Influence of data collection schemes on the Life Cycle Assessment of a municipal wastewater treatment plant. Water Res. 56, 292-303. doi:10.1016/j.watres.2014.03.014

Yoshida, H., Mønster, J., Scheutz, C., 2014b. Plant-integrated measurement of greenhouse gas emissions from a municipal wastewater treatment plant. Water Res. 61, 108-118. doi:10.1016/j.watres.2014.05.014

Yver Kwok, C.E., Müller, D., Caldow, C., Lebègue, B., Mønster, J.G., Rella, C.W., Scheutz, C., Schmidt, M., Ramonet, M., Warneke, T., Broquet, G., Ciais, P., 2015. Methane emission estimates using chamber and tracer release experiments for a municipal waste water treatment plant. Atmos. Meas. Tech. 8, 2853-2867. doi:10.5194/amt-8-2853-2015 